\title{
Innovation building materials in energy-saving wall systems of historical buildings in Saint Petersburg
}

\author{
Svetlana Golovina ${ }^{1}$, Yurii Tikhonov ${ }^{1}$, Iulia Sokol ${ }^{1, *}$ \\ ${ }^{1}$ Saint Petersburg State University of Architecture and Civil Engineering, 4 Vtoraya \\ Krasnoarmeiskaya, 190005, Saint Petersburg, Russia
}

\begin{abstract}
The article notes that the main heat losses during major repairs of buildings of historical development are associated with low thermal resistance of external wall fences, due to the lack of thermal insulation of balcony doors. The purpose of the study: to show a significant reduction in costs in the capital reconstruction of former apartment buildings, of which there are more than one and a half thousand in St. Petersburg, due to the use of innovative thermal insulation materials. Methods: thermal imaging, laboratory research. Results: as a result of studying the humidity regime, the experimental section of the wall, determining the dew point, resistance to vapor permeability, air permeability, and construction properties of historical bricks, the authors suggest that buildings of historical development follow the rule that provides for insulation of the external walls of these buildings from the inside.
\end{abstract}

\section{Introduction}

The main causes of heat loss during major repairs, including buildings of historical development: low thermal resistance of external fences (walls, attic coverings, defects in the interfaces of balcony doors, window sashes, shortcomings of engineering solutions for heated buildings, including stairwell and Elevator blocks, stairwells). Imperfection of heating, natural ventilation and hot water supply systems. System implementation of energy-saving solutions will significantly reduce operating costs in a residential building by 2-2.5 times. At the same time, the specific share of energy saving due to urban planning solutions will be $8-10 \%$, architectural and planning solutions - up to $15 \%$, structural systems - up to $25 \%$, heating and ventilation systems - up to $30 \%$, operating technologies (installation of devices for accounting, monitoring and regulating heat, water and electricity consumption - up to $20 \%$.

\section{Methods}

Full-scale tests of fragments and energy-saving systems of the exterior walls of a historical building.

\footnotetext{
* Corresponding author: usokol2009@mail.ru
} 
Short historical summary. Building under study: House of society of civil engineers (SCE) (Fig. 1), located at the address: Saint Petersburg, Serpukhovskaya str., 10, author of the project architect Moshinsky I. Yu.

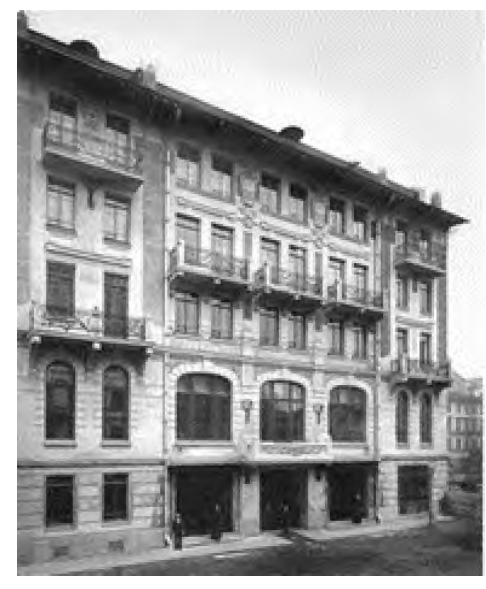

a

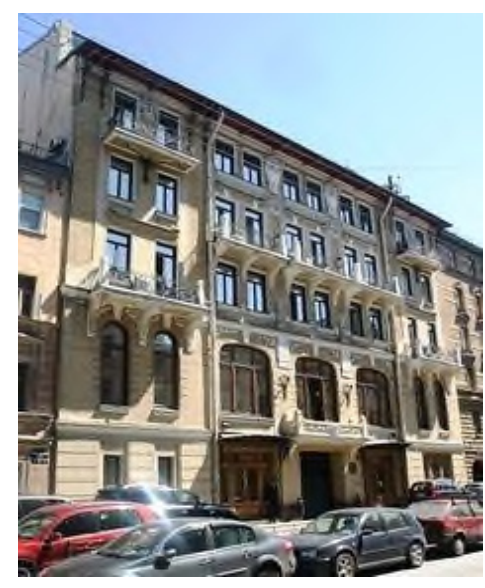

b

Fig. 1. a - House of society of civil engineers, photo of the 1900s; b - modern photography.

The society was officially approved on December 17, 1894. Its purpose (graduates of the Institute of civil engineers) was friendly mutual assistance, improvement of professional knowledge and exchange of creative experience.

The building, built in 1901-1902 years of the XX century, combines the features of eclecticism and art Nouveau. The appearance reflects the structure of a multifunctional building (public spaces and hotel-type housing). Decorative elements on the facade contain symbols of the civil engineer profession.

The experimental section of the wall is located between axes 7-9 (Fig.2). The wall is self-supporting, so the floor beams do not rest on the wall, which excludes possible cold bridges.

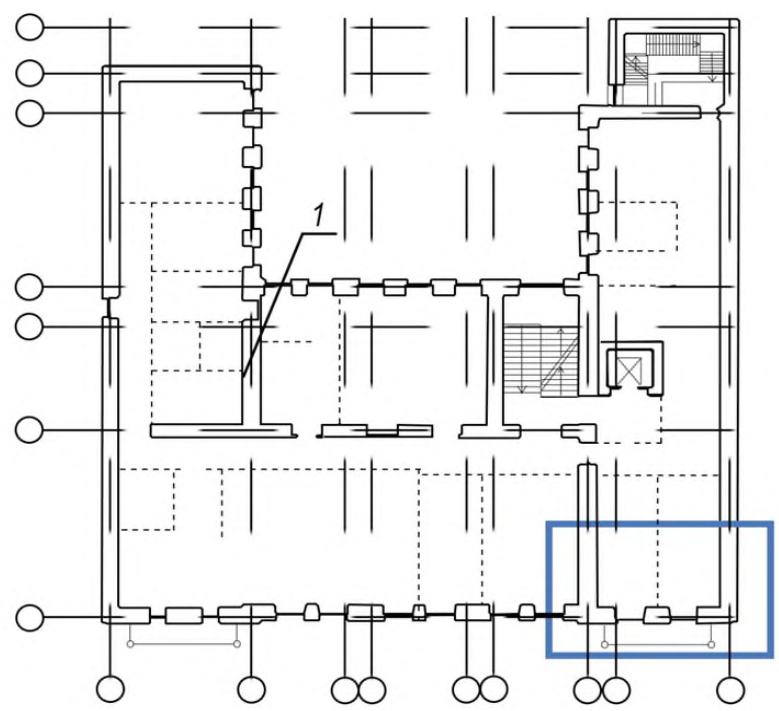

Fig. 2. Plan of the 3rd floor of the building under study with an experimental section of the wall (in a frame). 
Floor sections of walls and their description

3rd floor - external fencing system with the use of fiberglass URSA Board, steamhydro-protective film "Tyvek" and KNAUF drywall;

4th floor - external fencing system with the use of extruded polystyrene foam, steamhydro-protective film "Tyvek" and drywall;

5th floor - external fencing system with the use of ROCKVOOL mineral wool basalt slab, "Tyvek" steam-hydro-protective film and KNAUF drywall.

The building is included in the Unified state register of cultural heritage objects (historical and cultural monuments) of the peoples of the Russian Federation as a cultural heritage object of regional significance on the basis of the order of the Committee for state control over the use and protection of historical and cultural monuments No. 10-22 dated 21.07.2009.

In 2017-2018, the building was restored.

3rd floor

The research material is URSA glass wool
Fragment 1

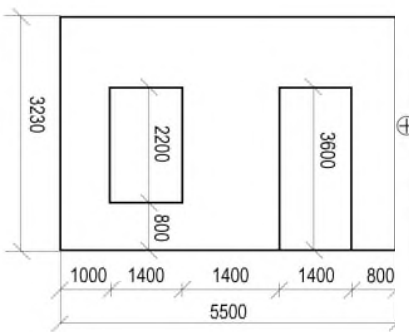

Fragment 2

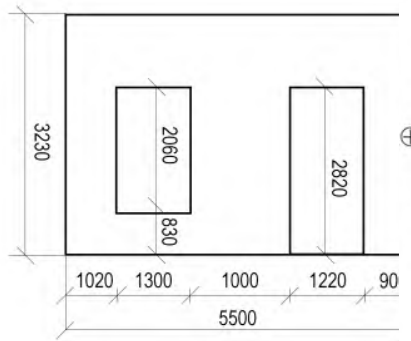

Fragment 3

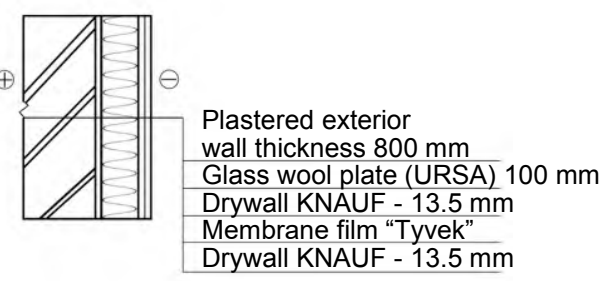

4rd floor

The research material is extruded polystyrene (PENOPLEX)

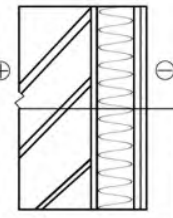

Plastered exterior wall thickness $800 \mathrm{~mm}$

Extruded polystyrene (PENOPLEX) $100 \mathrm{~mm}$

Drywall KNAUF - $13.5 \mathrm{~mm}$

Membrane film "Tyvek"

Drywall KNAUF - $13.5 \mathrm{~mm}$

5rd floor

The research material is basalt stone slab (Rockwool)

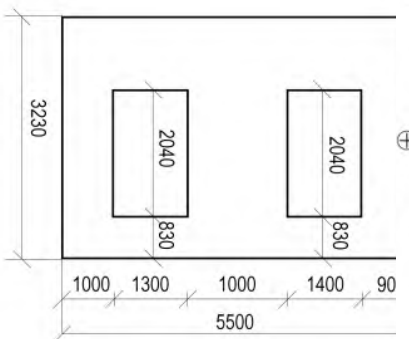

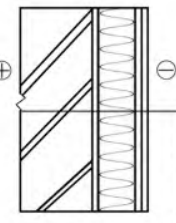

Plastered exterior

wall thickness $800 \mathrm{~mm}$

mineral Wool plate (Rockwool)

Drywall KNAUF - $13.5 \mathrm{~mm}$

Membrane film "Tyvek"

Drywall KNAUF - $13.5 \mathrm{~mm}$

Fig. 3. Features of insulation of fragments of walls of experimental sites. 
The main role in the thermal balance of the external fence is played by thermal insulation materials (TIM). The most important place among them is occupied by noncombustible mineral wool materials (made of stone (basalt) and glass staple fiber), which are used in low-rise construction. For comparison, products made of poroplast (mainly extruded polystyrene) are also taken. TIM were taken as floor insulation of the outer wall.

During the experiment in the mentioned historical building, bricks taken from the wall of the fifth floor were examined. According to the type of stamp, the period of manufacture and the manufacturer of the material were determined. Bricks with the mark "MK" and "MK 45" were produced at the factory of M. F. Kononov, which produced bricks from the beginning of the XX century (the time of construction of the building in 1901-1902).

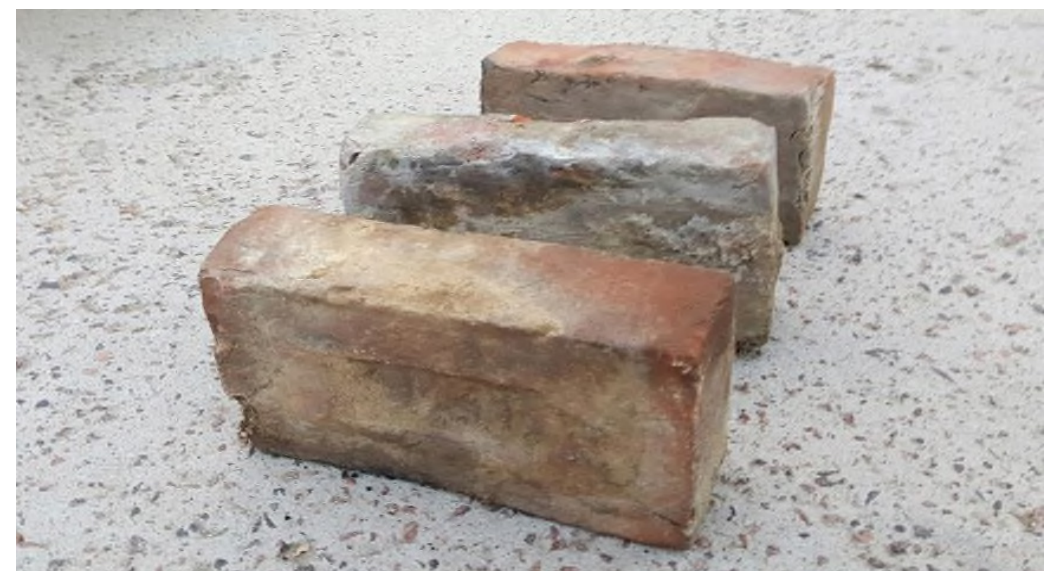

Fig. 4. Ceramic bricks of the building under study.

The bricks were tested at the spbgasu building materials Testing center in accordance with GOST 530-2012 "ceramic Bricks and stones. General specifications».

Technical properties of the brick of the building under study.

Brick grade KR -255 125 70/M200/2,0/30; medium density class 2,0; strength grade $\mathrm{M} 200\left(\mathrm{~kg} / \mathrm{cm}^{3}\right)$; frost resistance F30; fire resistance class NG2.

Tests have shown that the brick of the historical building during the operation of the building (from 1904 to the present, i.e. for 115 years of operation), the ceramic brick of the external walls has retained its construction properties and meets the main requirements of modern regulatory documents.

Depending on the location of the TIM in the wall system, there are three options according to figure 5 .

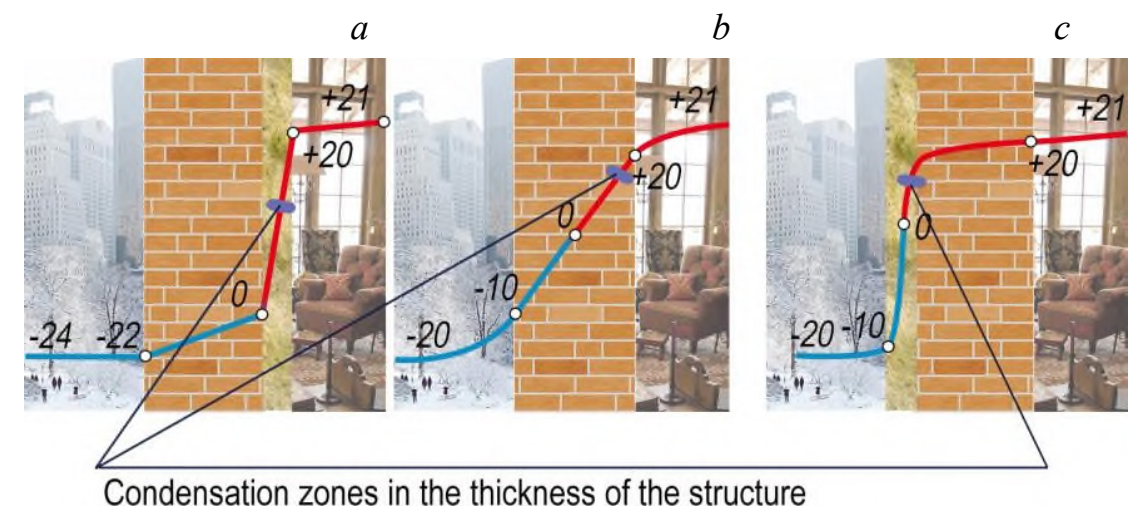


Fig. 6. Options for the position of the insulation layer in the external walls of buildings. Where: awithout a layer of insulation; b- the insulation on the outside; c- the insulation is inside (our version).

In order to study the mode of operation of experimental systems of sections of external walls of the building under investigation in operational conditions, their tests were carried out. For comparison, a real external wall without insulation was tested. The tests were carried out in two periods of autumn - winter (November - December 2018 and winter (February 2019). During the testing period, the experimental rooms were heated, but not operated.

Table 1. Characteristics of experimental wall sections and materials.

\begin{tabular}{|c|c|c|c|c|c|}
\hline \multirow[b]{2}{*}{ Indicators } & \multicolumn{4}{|c|}{ Plot type } & \multirow[t]{2}{*}{ Note } \\
\hline & $\begin{array}{l}\text { 2nd } \\
\text { floor }\end{array}$ & 3nd floor & $\begin{array}{l}\text { 4nd } \\
\text { floor }\end{array}$ & 5nd floor & \\
\hline $\begin{array}{l}\text { Area (surface) of the } \\
\text { wall, } \mathrm{m}^{2}\end{array}$ & & 9.65 & 12.26 & 11.63 & \\
\hline $\begin{array}{lll}\text { Area of } & \text { window } \\
\text { openings, } m^{2} & \end{array}$ & & 3.08 & 5.51 & 2.77 & \\
\hline Doorway area, $\mathrm{m}^{2}$ & & 5.04 & - & 3.44 & \\
\hline $\begin{array}{l}\text { The thickness of the } \\
\text { exterior walls, } \mathrm{mm} \\
\text { including: }\end{array}$ & \multicolumn{4}{|l|}{770} & \\
\hline $\begin{array}{l}\text { Insulation; } \\
\text { combustibility }\end{array}$ & & $\begin{array}{l}\text { URSA glass } \\
\text { plate, NGP-30 }\end{array}$ & $\begin{array}{l}\text { EPPS, } \\
\text { G-2, } \\
\text { M-35 }\end{array}$ & $\begin{array}{l}\text { PAROK M-100 } \\
\text { stone slab }\end{array}$ & \\
\hline $\begin{array}{lll}\text { Moisture } & \text { content } & \text { by } \\
\text { weight, \% } & & \\
\end{array}$ & & 0.5 & 0.4 & 0.1 & \\
\hline $\begin{array}{l}\text { Full-bodied ceramic } \\
\text { brick }\end{array}$ & \multicolumn{4}{|c|}{ M - 200} & \\
\hline $\begin{array}{l}\text { External plaster, lime } \\
\text { sand, R, kgf/s }\end{array}$ & \multicolumn{4}{|l|}{50} & \\
\hline $\begin{array}{l}\text { Tyvek membrane, } \rho_{0} \\
\mathrm{~kg} / \mathrm{m}^{3}\end{array}$ & - & \multicolumn{3}{|l|}{0,06} & \\
\hline $\begin{array}{l}2 \text { layers of drywall } \\
\text { sheets KNAUF, mm }\end{array}$ & \multicolumn{4}{|c|}{$13.5 \times 2=27$} & \\
\hline
\end{tabular}

Table 1. Technical properties of the bricks of the building under study.

\begin{tabular}{|l|c|}
\hline \multicolumn{1}{|c|}{ Types of tests } & Indicators, units of measurement \\
\hline Water absorption & $11.5, \%$ \\
\hline Average density & $1890, \mathrm{~kg} / \mathrm{m}^{3}$ \\
\hline Tensile strength in bending & $3.1 \mathrm{MPa}$ \\
\hline The limit of compressive strength & $23.7 \mathrm{MPa}$ \\
\hline
\end{tabular}

Brand of brick KR- 255125 70/M200/2,0/30; average density class 2,0; strength grade $\mathrm{M} 20, \mathrm{~kg} \mathrm{f} / \mathrm{cm}_{2}$; frost resistance F30, fire resistance class NG2.

During the operation of the building (from 1904 to the present, i.e. for 115 years of operation), the ceramic brick of the exterior walls has retained its construction properties. Tests have shown that the brick of the historic building meets the main indicators of modern regulatory requirements. 
Table 3. Technical characteristics of thermal insulation materials used in the work.

\begin{tabular}{|c|c|c|c|c|}
\hline${ }^{\text {View }}$ & Name & $\begin{array}{l}\text { Average density, } \\
\mathrm{kg} / \mathrm{m}^{3}\end{array}$ & $\begin{array}{c}\text { Thermal } \\
\text { conductivity } \\
, W / \mathbf{m} \cdot \mathrm{K}\end{array}$ & $\begin{array}{c}\text { Combustibi } \\
\text { lity }\end{array}$ \\
\hline Fiberglass plate & URSA, P-30 & 28 & 0.039 & NG \\
\hline Stone slab & $\begin{array}{l}\text { Rockwool, } \\
\text { M-100 }\end{array}$ & 90 & 0.045 & NG \\
\hline $\begin{array}{l}\text { Plate made of extruded } \\
\text { polystyrene foam }\end{array}$ & $\begin{array}{c}\text { PENOPLEX, } \\
\text { EPPS, } \\
\text { M - } 35\end{array}$ & 35 & 0.028 & G-2 \\
\hline
\end{tabular}

Changing the thickness of the insulating layer and thus thermal resistance of the fence, you can easily calculate required thermal resistance for any type of building in any climatic area of Russia, based on current energy requirements. High thermal insulation properties of such panels reduce the cost of heating the building, provide a high degree of comfort. The code of rules "thermal protection of buildings" does not apply to thermal protection of: religious buildings; - buildings, structures and structures that are classified as cultural heritage objects in accordance with the legislation of the Russian Federation.

Indeed, the facades and internal structures of the premises of the first and second floors of the building under study are protected by KGIOP. Therefore, to increase the thermal resistance of the outer fence, you can offer insulation of the inner surface of the wall.

Advantages of this method:

- insulation is made floor-by-floor without the use of scaffolding;

- work is carried out in an indoor area without access to precipitation.

- no "bridges" of cold

Disadvantages of this technique:

- the external load-bearing part of the wall freezes in winter;

- for the device of thermal insulation, the surface of the inner part of the wall must be freed from heating devices;

- the junction of the floor slabs and the node of their support on the outer wall are cold bridges.

To minimize moisture accumulation during the cold period, a vapor barrier layer should be provided in the enclosing structure. As an experimental material, a vapor barrier of the "Tyvek" type was used.

\section{Research results and discussion}

To visualize the results of the experiment, let's compare a section of the wall of the building under study with and without insulation. On the second floor of the building under study, external and internal front wall finishing was made without insulation: external walls with a thickness of 3 bricks $(770 \mathrm{~mm})$, with decorative plaster, $1.5 \mathrm{~mm}$ thick on a $3 \mathrm{~cm}$ thick primer, on the inside a layer of primer on a reinforcing plastic mesh, $1 \mathrm{~cm}$ thick and a decorative layer, $1.5 \mathrm{~mm}$ thick. The experimentally determined heat transfer resistance of the experimental section of the outer wall of the former apartment building located at Serpukhovskaya 10 is equal to $1.0\left(\mathrm{~m}^{2} \cdot \mathrm{K}\right) / \mathrm{W}$. (table 4), which does not meet modern standards for energy conservation. On the fifth floor of the building under study, where as 
insulation of the inner layer of the wall in accordance with Fig. 3 a material based on basalt fiber was taken, the heat transfer resistance is $3.32\left(\mathrm{~m}^{2} \cdot \mathrm{K}\right) / \mathrm{W}($ table 5$)$.

Table 4. Heat transfer resistance of the components of the outer wall of the experimental section without the use of a thermal insulation layer.

\begin{tabular}{|c|c|c|c|c|}
\hline № & Wall material & $\begin{array}{c}\text { Layer } \\
\text { thickness, } \\
\quad \delta, \mathbf{m}\end{array}$ & $\begin{array}{c}\text { Calculated } \\
\text { thermal } \\
\text { conductivity of } \\
\text { the material, } \\
\lambda,\left(\mathbf{W} /\left(\mathbf{m}^{2} \mathbf{K}\right)\right.\end{array}$ & $\begin{array}{l}\text { Thermal } \\
\text { resistance of } \\
\text { the structure } \\
R,\left(\mathbf{m}^{2} \mathbf{K}\right) \mathrm{W}\end{array}$ \\
\hline 1 & $\begin{array}{l}\text { Cement-sand mortar (inner surface of the } \\
\text { wall) }\end{array}$ & 0.01 & 0.93 & 0.01 \\
\hline 2 & Full-bodied ceramic brick $1800 \mathrm{~kg} / \mathrm{m}^{3}$ & 0.77 & 0.81 & 0.95 \\
\hline 3 & $\begin{array}{l}\text { Lime-sand mortar (the outer part of the } \\
\text { wall) }\end{array}$ & 0.03 & 0.81 & 0.04 \\
\hline \multicolumn{4}{|c|}{ Total thermal resistance of the outer wall } & 1.00 \\
\hline
\end{tabular}

Table 5. The resistance to heat transfer of enclosing structures with an inner layer of non-combustible insulating material.

\begin{tabular}{|c|c|c|c|c|}
\hline № & Wall material & $\begin{array}{c}\text { Layer } \\
\text { thickness, } \\
\delta, \mathrm{m}\end{array}$ & $\begin{array}{l}\text { Calculated } \\
\text { thermal } \\
\text { conductivity of } \\
\text { the material, } \lambda \text {, } \\
\left(\mathbf{W} /\left(\mathbf{m}^{2} \mathbf{K}\right)\right.\end{array}$ & $\begin{array}{l}\text { Thermal } \\
\text { resistance of } \\
\text { the structure } \\
R,\left(\mathrm{~m}^{2} \mathrm{~K}\right) \mathrm{W}\end{array}$ \\
\hline 1 & $\begin{array}{l}\text { Cement-sand mortar (inner surface } \\
\text { of the wall) }\end{array}$ & 0.01 & 0.93 & 0.01 \\
\hline 2 & Gypsum sheathing sheets "KNAUF" & 0.25 & 0.21 & 0.12 \\
\hline 3 & Mineral wool plate M-75 & 0.10 & 0.045 & 2.2 \\
\hline 4 & "Tyvek" & 0.1 & 0 & 0.00 \\
\hline 5 & $\begin{array}{l}\text { Masonry on the CPR of full-bodied } \\
\text { ceramic bricks } \mathrm{p}=1800 \mathrm{~kg} / \mathrm{m}^{3}\end{array}$ & 0.77 & 0.81 & 0.95 \\
\hline 6 & $\begin{array}{l}\text { Lime-sand mortar } \\
\text { (the outer part of the wall) }\end{array}$ & 0.03 & 0.81 & 0.04 \\
\hline \multicolumn{4}{|c|}{$\begin{array}{l}\text { Total thermal resistance of an external wall with an internal thermal insulation } \\
\text { layer }\end{array}$} & 3.32 \\
\hline
\end{tabular}

$\left({ }^{\circ} \mathrm{C}\right)$

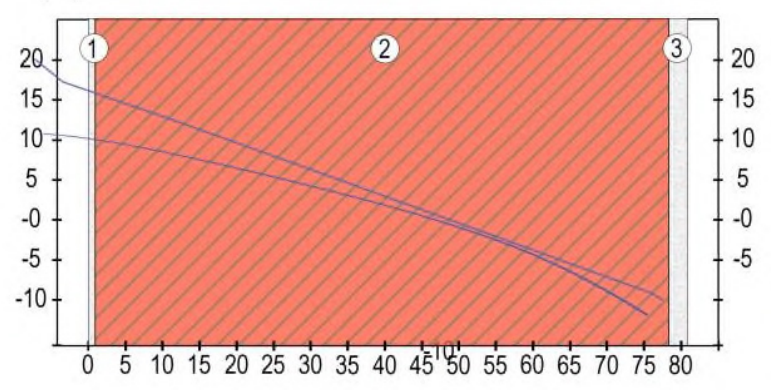
- Temperature
(1) $[10 \mathrm{~mm}]$ of a Cement-sand mortar
— dewpoint temperature
Condensation zone
(2) $[770 \mathrm{~mm}]$ Masonry on the CPR of full-bodied ceramic bricks $1800 \mathrm{~kg} / \mathrm{m}^{2}$
(3) [30 mm] Lime-sand solution 
Fig. 6. Real heat transfer resistance of the experimental section of the external walls of the building under study.

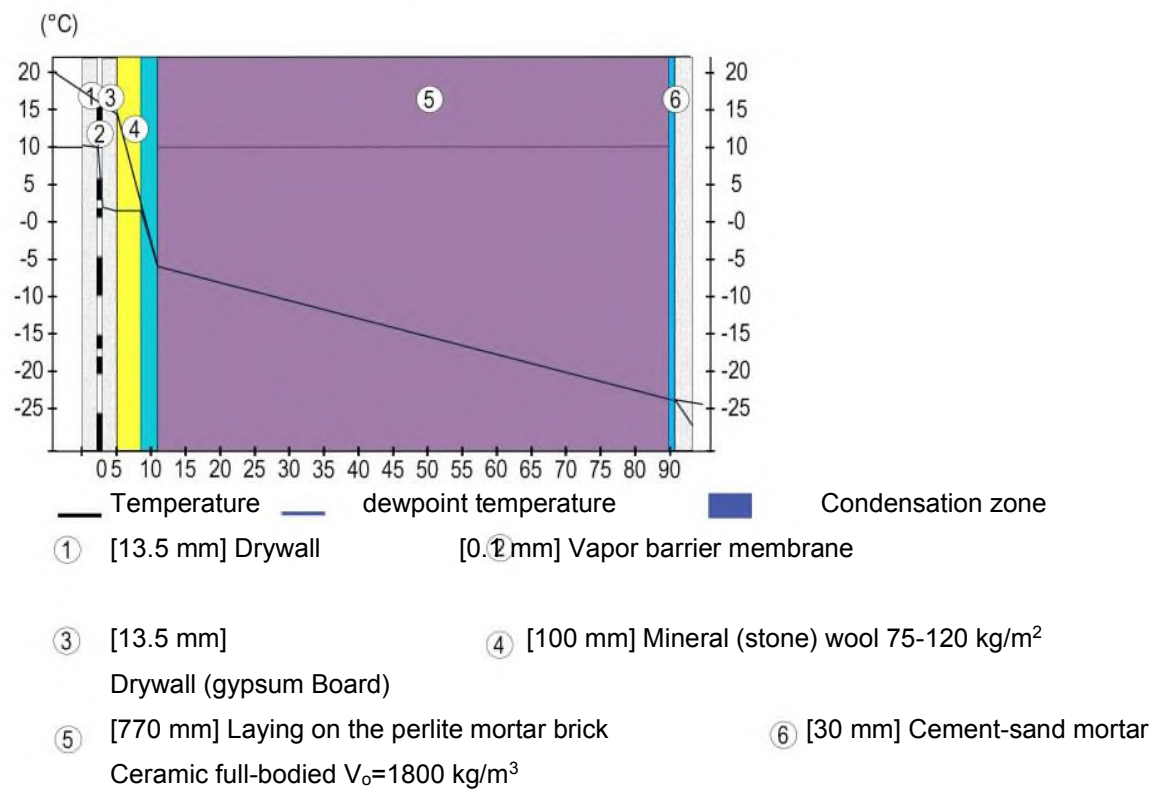

Fig. 8. Resistance to heat transfer of the experimental section of the wall in the room of the 5 th floor using non-combustible insulation rockwool from the inside.

Consider figure 7:

Based on figure 7, it follows that the wall in all its thickness will be "cold". Accordingly, the wall will not meet the energy efficiency requirements. In addition, moisture will accumulate inside the wall, which will cause deterioration of the material characteristics and, in General, a decrease in the properties of the wall.

Consider figure 8:

In this experiment, the structural layer of the wall, as in the first case, is "cold". Insulation, mineral wool plate, being inside, remains "warm". The dew point is located near the inner surface of the structural layer, and if there is a possible temperature difference, moisture will also accumulate inside the wall. However, this method can only be implemented if accurate calculations are made and all conditions are met. For example, the use of a layer of vapor barrier material on the side of a heated room.

\section{Conclusions}

Based on the above, it should be concluded that the walls of apartment buildings in the historical center of St. Petersburg, in order to preserve the historical facade decoration, can be insulated from the inside, bringing them to the requirements for energy efficiency, according to Federal law No. 261 "On energy saving and energy efficiency improvement and on amendments to certain legislative acts of the Russian Federation" dated 23.11.2009.

For insulation of internal surfaces of external fences, we recommend using fibrous thermal insulation materials made of artificial fiber. These are slabs and mats made of glass and stone wool. The material has a low coefficient of thermal conductivity ( $\lambda$ from 0.033 to $\left.0.048 \mathrm{~W} /\left(\mathrm{m}^{* \circ} \mathrm{C}\right)\right)$, high heat capacity $\left(\mathrm{C}=1000-1050 \mathrm{~J} /\left(\mathrm{kg}^{* \circ} \mathrm{C}\right)\right)$, and is non-combustible. 
These properties are especially important when used for insulation of external walls from the inside.

\section{References}

1. A.G. Bulakh, Stone decoration of St. Petersburg. Masterpieces of architectural and monumental art of the Northern capital (ZAO Tsentrpoligraf, Moscow, 2009)

2. E.D. Yukhneva, Petersburg apartment buildings. Essays from the history of everyday life (ZAO Esentrpoligraf, Moscow, 2008)

3. Yu.M. Tikhonov, S.G. Golovina, A.F. Sharapenko, Modern construction materials and architectural and construction systems of buildings, architectural and construction systems of buildings (SPBGASU, Saint Petersburg, 2018)

4. Yu.M. Tikhonov, Yu.P. Panibratov, Yu.G. Meshcheryakov, V.B. Zverev, O.M. Malakhov, Architectural materials science (Academy publishing center, Moscow, 2013)

5. Yu.M. Tikhonov, S.G. Golovina, A.F. Sharapenko, Modern building materials and architectural and construction systems of buildings (SPBGASU, Saint Petersburg, 2016)

6. V.B. Zverev, Yu.P. Panibratov, Yu.M. Tikhonov, Guide to building materials (SPBGASU, LLC "SPAERO", Saint Petersburg, 2002)

7. T.G. Maklakova, S.M. Nanasova, Structures of civil buildings (ASV, Moscow, 2000)

8. G.I. Gorchakov, Yu.M. Bazhenov, Construction materials (Stroyizdat, Moscow, 1986)

9. R.Z. Rakhimov, N.S. Shelikhov, T.V. Smirnova, Stone wool insulation (ASV, Moscow, 2010)

10. G. Kirstein, The art of Building (N. Kimmel, Riga, 1904)

11. V.G. Lisovsky, Architecture of St. Petersburg. Three centuries of history (Saint Petersburg, Slavia, 2004)

12. P.N. Petrov, Materials on the history of the construction part in Russia (Academy of Sciences, Saint Petersburg, 1986)

13. Yu.P. Gorlov, Technology of heat-insulating and acoustic materials and products (Higher school, Moscow, 1989)

14. A.V. Chinese, The Technology of thermal insulation materials (Publishing house of literature on construction, Moscow,1970)

15. SP 50.13330.2012 Thermal protection of buildings. Updated version of SNiP 23-022002

16. K.F. Fokin, Construction heat engineering of enclosing parts of buildings (Stroizdat, Moscow, 1973) 